\title{
RANCANG BANGUN E-BOOK "KEGIATANKU DALAM MENJAGA LINGKUNGAN ALAMKU" PELAJARAN IPS KELAS V SD
}

\author{
Ervhy Indra Puspita, Tin Rustini, Dinie Anggraeni Dewi \\ Pendidikan Guru Sekolah Dasar, Kampus Daerah Cibiru, Universitas Pendidikan \\ Indonesia \\ Jl. Pendidikan No. 15, Cibiru Wetan, Bandung 40625, Jawa Barat \\ Email: ervhyindrapuspita15@upi.edu, tinrustini@yahoo.com, \\ anggraenidewidhinie@gmail.com
}

\begin{abstract}
Abstrak
Penelitian desain dan pengembangan ini bertujuan: 1) Menghasilkan produk $e$-book untuk mata pelajaran IPS kelas V; 2) Mengetahui kelayakan hasil uji produk e-book untuk mata pelajaran IPS kelas V; 3) Mengetahui respon guru dan siswa terhadap produk $e$-book untuk mata pelajaran IPS kelas V. Metode penelitian ini mengacu pada model pengembangan ADDIE yang memiliki 5 tahapan, yakni: 1) Analyze; 2) Design; 3) Development; 4) Implementation; 5) Evaluation. Penelitian ini menghasilkan produk e-book multimedia yang berbasis flipbook berupa aplikasi sebagai alat bantu siswa dalam memahami materi interaksi manusia dengan lingkungan alam. Hasil skor penilaian validasi produk pada ahli media sebesar 93,75\% (sangat baik), pada ahli materi 95,00\% (sangat baik), dan pada ahli bahasa $90,00 \%$ (sangat baik). Selanjutnya hasil respon guru dan siswa terhadap e-book secara berurutan $87,50 \%$ (sangat baik) dan $87,86 \%$ (sangat baik). Dari hasil tersebut, dapat dikatakan bahwa e-book "Kegiatanku dalam Menjaga Lingkungan Alamku" layak digunakan dalam pembelajaran IPS.
\end{abstract}

Kata Kunci: $e$-book berbasis flipbook, multimedia, pengembangan

Abstract

This design and development research aims to: 1) Develop an e-book product designed for social studies subject grade V; 2) Find out the feasibility of e-book product; 3) Find out the responses of teachers and students about e-book. This research refers to design ADDIE model procedurs, consisting of: 1) ) Analyze; 2) Design; 3) Development; 4) Implementation; 5) Evaluation. This research produced a multimedia e-book based on flipbook in the form of an application as a tool for students to understand material of human interactions with the natural environment. The result of the feasibility assessment scores from media experts are $93.75 \%$ (very decent), material experts $95.00 \%$ (very decent), and linguists $90.00 \%$ (very decent). Later, the result of teacher's responses and student's responses in sequences are $87,50 \%$ (very decent) and $87,86 \%$ (very decent). Based on the result, the e-book "Kegiatanku dalam Menjaga Lingkungan Alamku is suitable for use in social studies learning.

Key Words: flipbook based in flipbook, multimedia, development rease

\section{PENDAHULUAN}

Pada kondisi pandemi Covid-19 yang sedang dialami di berbagai belahan dunia mengharuskan pembelajaran dilakukan secara daring. Pembelajaran yang biasanya dilakukan secara tatap muka di kelas diubah menjadi pembelajaran secara tatap maya dengan menggunakan digital tools. Meskipun pembelajaran dilakukan secara daring, perencanaan harus direncanakan sebaik mungkin. Salah satu unsur penting dalam perencanaan pembelajaran adalah 
media pembelajaran. Menurut $\mathrm{H}$. Malik (dalam Sumiharso \& Hasanah, 2018) media pembelajaran merupakan sesuatu yang dapat digunakan untuk menyalurkan pesan pembelajaran yang dapat merangsang perhatian, minat, pikiran serta perasaan pembelajar/siswa dalam proses pembelajaran untuk mencapai tujuan pembelajaran tertentu. Media pembelajaran sebagai alat bantu mengajar dapat memudahkan siswa untuk mempelajari pembelajaran yang bersifat abstrak menjadi lebih konkret/nyata (Supriyono, 2018). Tak hanya itu, penggunaan media dalam proses pembelajaran dapat membangkitkan semangat dan minat belajar siswa, membangkitkan nalar yang teratur serta sistematis, dan juga dapat mengembangkan nilai-nilai yang ada dalam diri siswa.

Penggunaan media pembelajaran berbasis digital pada masa pembelajaran jarak jauh saat pandemi COVID-19 menjadi salah satu solusi untuk menciptakan pembelajaran yang efektif dan dapat membantu siswa untuk memahami materi yang disampaikan. Karena tujuan media pembelajaran adalah untuk membantu siswa dalam memahami proses pembelajaran, maka media pembelajaran harus disesuaikan dnegan karakteristik siswa dan disesuaikan dengan gaya belajar masing-masing siswa, yakni diantaranya audio, video, audiovisual, serta kinestetik.

Salah satunya adalah media pembelajaran e-book. Secara sederhana, e-book dapat diartikan sebagai buku elektronik atau buku digital. E-book merupakan proses pendigitasian buku konvensional biasa (Martha, Z. D., Adi, E. P., \& Soepriyanto, 2018). E-book merupakan salah satu media pembelajaran yang dapat memfasilitasi berbagai gaya belajar masing-masing siswa dikarenakan sebuah e-book tak hanya berisikan teks dan gambar saja, melainkan dapat disisipi video, audio, power point, dan bahan ajar lainnya dalam satu kesatuan e-book. E-book biasanya dilengkapi oleh fitur-fitur interaktif yang dapat mendukung kegiatan belajar mengajar, seperti dapat disisipi video, konten grafik, audiovisual, hyperlink, kuis, animasi serta fitur pencarian (Susantini et al., 2021).

Media pembelajaran $e$-book dapat digunakan untuk seluruh mata pelajaran, tak terkecuali mata pelajaran Ilmu Pengetahuan Sosial. IPS merupakan ilmu yang menjelaskan hubungan antar manusia dengan konteks sosial dari hasil mengkaji berbagai ilmu sosial (sejarah, ekonomi, politik, sosiologi, antropologi, psikologim geografi dan filsafat) yang disederhanakan dan dirangkum menjadi IPS untuk tujuan pendidikan guna untuk penanaman kesadaran bertanggung jawab sebagai warga negara pada sesama manusia, negara dan alam sekitar (Nasution \& Lubis, 2018; Rahmad, 2016). Tak hanya itu, Pendidikan IPS di Indonesia pada dasarnya mempersiapkan dan membekali peserta didik untuk menjadi warga negara yang memiliki kemampuan untuk menguasai pengetahuan (knowledge), keterampilan (skill), sikap dan nilai (attitudes and values) yang dapat bermanfaat bagi kehidupannya sehari-hari sebagai dasar untuk memecahkan masalah, mengambil keputusan dan berpartisipasi dalam berbagai kegiatan kemasyarakatan agar menjadi warga negara yang baik 
dengan cara melibatkan seluruh panca inderanya (Rustini, 2016; Sapriya, 2009; Siska, 2016)

Dari definisi di atas, dapat ditarik sebuah poin bahwa pembelajaran IPS memiliki kaitan yang erat dengan lingkungan alam dan lingkungan sosial budaya. Lingkungan alam dan lingkungan sosial budaya merupakan aspek sosial yang sangat berkaitan erat dengan manusia dan tidak dapat dipisahkan. Sehingga dibutuhkan penekanan niilai dan makna pentingnya menjaga alam dalam pembelajaran IPS.

Dewasa ini, berbagai bencana alam terjadi pada awal tahun 2021, dari bencana banjir di berbagai daerah serta bencana longsor (Hakim, 2021). Hal tersebut menjadi salah satu akibat dari ulah manusia yang tidak dapat menjaga alamnya dengan baik serta rendahnya kepedulian akan lingkungan. Hal tersebut didasari dari data Kementerian Kesehatan hanya $20 \%$ dari total masyarakat Indoesia yang peduli terhadap kebersihan lingkungan dan dampaknya kepada kesehatan.

Berdasarkan studi pendahuluan pada buku siswa kelas V semester 1 Tema 3 Revisi 2019 Terbitan Kemendikbud, didapati bahwa materi bentuk interaksi manusia dan lingkungannya dimuat dalam tema 3 hingga tema 4 dengan kedalaman materi yang singkat serta disajikan dalam bentuk teks bacaan dan gambar. Hal ini menjadikan proses pembelajaran IPS khususnya pada bentuk interaksi manusia dengan lingkungan alam belum maksimal memberikan makna dan nilai-nilai penting dari materi yang berkaitan.

Berdasarkan berbagai permasalahan yang ditemukan, maka penelitian pengembangan ini bertujuan untuk: 1) Mengetahui rencangan pengembangan media $e$ book "Kegiatanku dalam Menjaga Lingkungan Alamku"; 2) Mengethaui kelayakan hasil uji media e-book "Kegiatanku dalam Menjaga Lingkungan Alamku"; dan 3) Mengetahui respon guru dan siswa terhadap media e-book "Kegiatanku dalam Menjaga Lingkungan Alamku".

Materi pada media pembelajaran e-book "Kegiatanku dalam Menjaga Lingkungan Alamku" disajikan dengan berbagai format, yakni tak hanya teks dan gambar saja, melainkan video dan audio dengan tujuan untuk memfasilitasi berbagai gaya belajar siswa. Pembuatan media pembelajaran e-book dilakukan dnegan menggunakan perangkat lunak/software Flip PDF Professional. Software tersebut digunakan untuk membuat tampilan buku menjadi sebuah e-book berbentuk flipbook dnegan mengkonversi file PDF ke halamanbalik publikasi digital. Tak hanya itu, melalui software ini dapat menambahkan berbagai file untuk menyajikan e-book multimedia.

Manfaat dari penggunaan media pembelajaran e-book yakni, e-book dapat digunakan di mana saja dan kapan saja dan mudah karena tersimpan dalam bentuk file pada gadget, informasi yang disajikan dalam bentuk e-book bersifat kongkret sehingga tepat untuk siswa pada masa perkembangan operasional kongkret, dapat memfasilitasi pembelajaran yang bersifat individual khususnya pada masa pembelajaran daring. E-book dapat pula disisipi audio, video, power point, gambar, sehingga tidak hanya teks saja seperti 
pada buku cetak. (Hisbiyati \& Khusnah, 2017).

\section{METODE}

Jenis penelitian yang digunakan dalam penelitian ini adalah design and development, yaitu sebuah strategi untuk mengembangkan suatu produk tertentu dan menguji keefektifan produk tersebut. Richey \& Klein (2007) menyebutkan bahwa terdapat dua kategori dalam D\&D, yakni (1) Product and Tool Research dan (2) Model Research. penelitian ini tergolong ke dalam kategori pertama yaitu Product and Tool Research, yang memiliki fokus tujuan kepada proses perancangan dan pengembangan produk pendidikan, dianalisis dan dievaluasi produk tersebut dari segi desain dan pengembangan. Berdasarkan banyak penelitian terbaru, penelitian berfokus pada pengembangan produk dan alat berbasis teknologi (Richey \& Klein, 2014).

Prosedur penelitian pada penelitian ini menggunakan model pengembangan ADDIE. Menurut Barokati dan Annas (Kurna et al., 2019), model ADDIE merupakan salah satu model yang menjadi pegangan dalam mengembangkan pembelajaran yang efekif, dinamis dan mendukung pembelajaran yang hendak dibuat. Hal tersebut sependapat dengan Tegeh dan Kirna (Kurnia et al., 2019), bahwa model ADDIE merupakan model yang sistematis dalam menyusun desain pembelajaran.

Menurut Branch (2009) model ADDIE memiliki 5 tahapan, yakni: 1) Analyze atau tahapan menganalisis kebutuhan; 2) Design atau merancang materi; 3) Development atau mengembangkan apa yang telah dirancang menjadi sebuah produk; 4) Implementation atau mengimplementasikan produk kepada pengguna; 5) Evaluation atau menilai kualitas produk dari sebelum hingga sesudah produk diimpelentasikan.

Penelitian dilakukan pada bulan Juni 2021 yang dilakukan di SDN Panyileukan 262 Bandung. Uji coba dilakukan pada 31 siswa dan 2 orang guru kelas V SD Panyileukan 262 Bandung. Teknik pengumpulan data Teknik pengumpulan data untuk memperoleh data valid dilakukan dengan cara judgement/expert review mengenai validasi media, serta menggunakan Teknik survei untuk memperoleh respon guru dan siswa terhadap media e-book Interaksi Manusia dengan Lingkungannya. Instrument yang digunakan dalam penelitian ini adalah Angket Lembar Validasi Ahli Materi, Media dan Bahasa menggunakan Skala Likert serta angket survei uji coba kepada guru dan siswa.

Sedangkan analisis data dalam penelitian ini adalah menggunakan teknik analisis data deskriptif kuantitatif dan kualitatif. Data kuantitatif diperoleh dari lembar angket validasi media dan lembar survei uji coba guru dan siswa. Analisis data kelayakan produk menggunakan skor yang diperoleh dari Skala Likert. Dalam penelitian ini digunakan skala empat dan dikonversi ke dalam bentuk persenrtase dengan menggunakan rumus sebagai berikut:

$$
\begin{gathered}
P S=\frac{S}{N} \times 100 \% \\
\text { Ps = Persentase } \\
\mathrm{S}=\text { Jumlah Skor yang didapat } \\
\mathrm{N}=\text { Jumlah Skor Ideal }
\end{gathered}
$$


Kemudian hasil angka yang didapat dari perhitungan tersebut akan diubah menjadi bentuk data kualitatif berdasarkan kategori kelayakan dengan mengacu pada kriteria Interpretasi Skor (Arikunto, 2009) sebagai berikut:

Tabel 1 Tabel Kriteria Interpretasi Skor

\begin{tabular}{|l|c|c|}
\hline No & Skor dalam Persen $(\boldsymbol{\%})$ & Kategori Kelayakan \\
\hline 1. & $<21 \%$ & Sangat Tidak Layak \\
\hline 2. & $21-40 \%$ & Tidak Layak \\
\hline 3. & $41-60 \%$ & Cukup Layak \\
\hline 4. & $61-80 \%$ & Layak \\
\hline 5. & $81-100 \%$ & Sangat Layak \\
\hline
\end{tabular}

Setelah proses analisis, data akan disajikan dalam bentuk deskriptid kualitatif dengan kategori kategori Tidak Layak, Kurang Layak, Layak dan Sangat Layak.

\section{HASIL DAN PEMBAHASAN}

Fokus utama dalam penelitian ini adalah merancang sebuah media pembelajarana e-book dengan harapan dapat menjadi sebuah solusi permasalahan pembelajarana di sekolah. Dalam perancangannya, digunakan model ADDIE pada setiap kegiatannya, yakni sebagai berikut:

a. Tahap Analyze (Analisis)

Langkah pertama dalam pembuatan dan perancangan media yaitu melakukan sebuah analisis. Analisis yang dilakukan mencangkup analisis kompetensi dasar yang dituntut pada peserta didik, analisis materi sesuai dengan tuntutan kompetensi, dan analisis karakteristik peserta didik

b. Tahap Design (Perancangan)
Tahap desain merupakan tahapan merancang rancangan media secara keseluruhan sebelum memasuki tahapan pengembangan. Hal yang dilakukan pada tahap ini, diantaranya menentukan tim pengembangan produk, menentukan materi, membuat evaluasi, serta menjabarkan bagaimana rancangan desain media.

c. Tahap Development (Pengembangan)

Tahap pengembangan merupakan tahap pembuatan e-book. Pembuatan e-book dibantu dengan beberapa alat digital yakni seperti web canva.com, aplikasi anchor untuk menggunggah podcast, youtube untuk mengunggah video, Flip PDF Professional untuk mengubah PDF menjadi flipbook dan menyisipkan seluruh media, serta web appgeyser untuk mengubah file menjadi aplikasi android. 


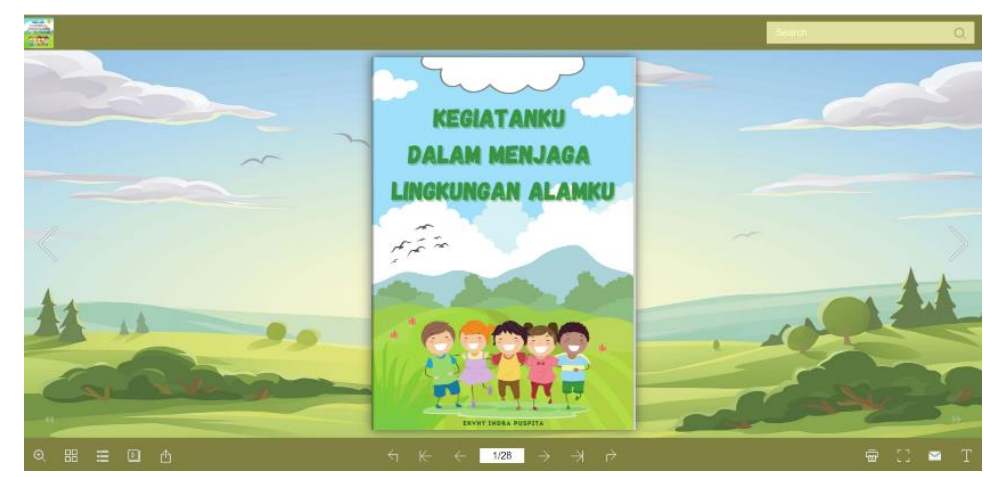

Gambar 2 Tampilan awal e-book

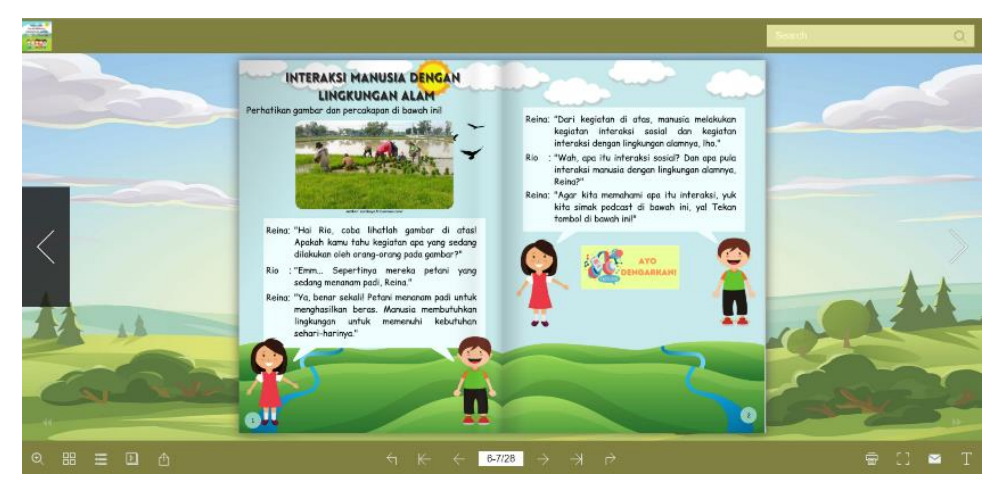

Gambar 1 Tampilan isi materi

Setelah melakukan tahapan pengembangan, dilakukan validasi media yang sudah dikembangkan oleh 3 orang validator, yakni validator ahli media, ahli materi dan bahasa. Hasil penilaian dari validator sebagai berikut:

Tabel 2 Hasil Validator Ahli Media

\begin{tabular}{|l|l|c|l|}
\hline No. & Aspek yang dinilai & Skor & Keterangan \\
\hline 1. & Kualitas Teknis & 15 & Sangat Baik \\
\hline 2. & Kualitas Desain & 29 & Sangat Baik \\
\hline 3. & Kualitas Prinsip & 16 & Sangat Baik \\
\hline Jumlah Skor & $\mathbf{6 0}$ & Sangat Baik \\
\cline { 1 - 2 } Rata-Rata (dalam Persen) & $\mathbf{9 3 , 7 5 \%}$ & \\
\hline
\end{tabular}

Berdasarkan tabel 2 di atas, hasil validasi dari segi media memperoleh skor $93,75 \%$, dapat dikatakan bahwa e-book ini layak dipakai dari segi media, baik dari segi kualitas teknis penggunaan, kualitas desain e-book, hingga kualtas prinsip kesesuaian. 


\section{Tabel 3 Hasil Validator Ahli Materi}

\begin{tabular}{|l|l|c|l|}
\hline No. & Aspek yang dinilai & Skor & Keterangan \\
\hline 1. & Aspek Isi/Materi & 43 & Sangat Baik \\
\hline 2. & Aspek Evaluasi & 14 & Sangat Baik \\
\hline Jumlah Skor & $\mathbf{5 7}$ & Sangat Baik \\
\hline \multicolumn{2}{|l}{ Rata-Rata (dalam Persen) } & $\mathbf{9 5 , 0 0 ~ \%}$ & \\
\hline
\end{tabular}

Berdasarkan tabel 3 di atas, hasil validasi dari segi materi memperoleh skor $95,00 \%$, dapat dikatakan bahwa $e$-book ini layak dipakai dari segi materi, baik dari segi KD hingga evaluasi.

Tabel 4 Hasil Validator Ahli Bahasa

\begin{tabular}{|l|l|c|l|}
\hline No. & Aspek yang dinilai & Skor & Keterangan \\
\hline 1. & Kebahasaan & 18 & Sangat Baik \\
\hline Jumlah Skor & $\mathbf{1 8}$ & Sangat Baik \\
\cline { 1 - 2 } Rata-Rata (dalam Persen) & $\mathbf{9 0 , 0 0 ~ \% ~}$ & \\
\hline
\end{tabular}

Berdasarkan tabel 2 di atas, hasil validasi dari segi kebahasaan memperoleh skor $90,00 \%$, dapat dikatakan bahwa $e$-book ini layak dipakai dari segi kebahasaan.

\section{d. Impelentation (Implementasi)}

Setelah melalui tahapan mengembangkan dan validasi $e$ book, dilakukan tahap implementasi atau uji coba. Uji coba dilakukan pada tanggal 30 Juni 2021 di melalui zoom meeting karena kondisi pandemi Covid-19. Subjek uji coba adalah siswa kela $\mathrm{V}$ dengan jumlah 31 siswa dan 2 orang guru kelas $\mathrm{V}$. Uji coba ini dilakukan untuk mengetahui respon siswa dan guru mengenai e-book pada materi interaksi manusia dengan lingkungan alam dengan cara peneliti mendemonstrasikan $e$ book. Setelah melakukan demonstrasi, siswa dan guru diberikan angket melalui google form untuk memberikan respon terhadap penggunaan media $e$ book.

Lembar skala respon siswa dan guru menggunakan skala likert skala 1 (sangat tidak setuju) hingga skala 4 (sangat setuju). Dari hasil penilaian skala respon siswa, hasil rerata skor penilaian produk adalah sebesar 85,36\% yang jika diinterpretasikan dengan mengacu pada kriteria skor menurut arikunto berada pada kategori "Sangat Baik". Selanjutnya, hasil penilaian skala respon guru, hasil rerata skor penilaian produk adalah sebesar $85,00 \%$ yang jika diinterpretasikan dengan mengacu pada kriteria skor menurut arikunto berada pada kategori "Sangat Baik".

Berdasarkan hasil di atas, disimpulkan bahwa media $E$-book "Kegiatanku dalam Menjaga Lingkungan Alamku" pada 
Pelajaran IPS Kelas V Sekolah Dasar telah memenuhi kelayakan dengan skor rata-rata dari responden sebesar $85,18 \%$ dan mendapat predikat "Sangat Baik" atau "Sangat Valid". Sehingga, media e-book valid dan layak digunakan di kelas V Sekolah Dasar.

\section{e. Evaluation (Evaluasi)}

Tahap evaluasi merupakan tahapan mengevaluasi hasil kerja dari tahap pertama hingga tahap akhir. Tahap evaluasi dilakukan untuk memperbaiki kualitas media e-book yang sudah dikembangkan.

Berdasarkan hasil analisis penelitian ini, dapat disimpulkan bahwa tujuan penelitian sudah tercapai. Berikut adalah kelebihan dari produk yang dikembangkan: 1) produk terdiri dari gabungan beberapa unsur multimedia seperti teks, gambar, video serta podcast untuk membantu siswa dalam memahami materi mengenai interaksi manusia dengan lingkungannya; 2) Siswa dapat menentukan kecepatan belajaranya masing-masing karena masing-masing siswa mengontrol aktivitas belajarnya sendiri; 3) E-book dapat memotivasi belajar siswa.

\section{SIMPULAN}

Pada penelitian pengembangan rancang bangun e-book ini, dapat disimpulkan bahwa:

1. Penelitian desain dan pengembangan E-book "Kegiatanku dalam Menjaga Lingkungan Alam" didesain dan dikembangkan dengan menggunakan prosedur model ADDIE.
2. Hasil pengujian kelayakan media ditinjau dari segi media, materi dan bahasa menunjukkan hasil nilai persentase rata-rata $95,00 \%$, $93,75 \%$, dan $90,00 \%$. Hasil akumulasi penilaian tersebut menunjukkan respon baik dengan kriteria "Sangat Baik/Valid". Kemudian, hasil dari uji coba kepada siswa dan guru menunjukan hasil persentase yaitu $87,86 \%$ dan 87,50\% "Sangat Baik".

3. Berdasarkan respon siswa, media E-book "Kegiatanku dalam Menjaga Lingkungan Alam" sangat menarik dan menyenangkan untuk digunakan dan meningkatkan motivasi dan semangat siswa dalam belajar karena $e$-book didesain dengan menarik dan materi mudah dipahami karena terbantu oleh ilustrasi gambar serta penjelasan dari audio dan video.

Berdasarkan penjelasan poin di atas, secara kesleuruhan dapat disimpulkan bahwa media E-book "Kegiatanku dalam Menjaga Lingkungan Alam" layak digunakan dalam pembelajaran IPS Kelas V sekolah dasar.

\section{DAFTAR PUSTAKA}

Arikunto, S. (2009). Prosedur Penelitian Suatu Pendekatan Prakits. PT. Rineka Cipta.

Branch, R. M. (2009). Approach, Instructional Design: The ADDIE. In Department of Educational Psychology and Instructional Technology University of Georgia (Vol. 53, Issue 9). 
Hakim, R. N. (2021). 5 Bencana Alam di Awal 2021, dari Longsor Sumedang hingga Gempa Sulbar. Kompas.Com. https://nasional.kompas.com/rea d/2021/01/18/12393831/5bencana-alam-di-awal-2021dari-longsor-sumedang-hinggagempa-sulbar?page $=$ all

Hisbiyati, H., \& Khusnah, L. (2017). Penerapan Media E-book Berekstensi Epub Untuk Meningkatkan Minat Dan Hasil Belajar Siswa Smp Pada Mata Pelajaran Ipa. Jurnal Pena Sains, $\quad 4(1), \quad 16$. https://doi.org/10.21107/jps.v4i 1.2775

Kurnia, T. D., Lati, C., Fauziah, H., \& Trihanton, A. (2019). Model ADDIE Untuk Pengembangan Bahan Ajar Berbasis Kemampuan Pemecahan Masalah Berbantuan 3D. Seminar Nasional Pendidikan Matematika, 1(1), 516-525.

Martha, Z. D., Adi, E. P., \& Soepriyanto, Y. (2018). E-book berbasis Mobile learning. Jurnal Kajian Teknologi Pendidikan, l(2), 109-114. http://journal2.um.ac.id/index.p hp/jktp/article/view/3705/2775

Nasution, T., \& Lubis, M. A. (2018). Konsep Dasar IPS. In Konsep Dasar IPS. Samudera Biru. https://doi.org/10.21067/press.7.

Rahmad. (2016). Kedudukan Ilmu Pengetahuan Sosial ( IPS ) pada Sekolah Dasar. Muallimuna: Jurnal Madrasah Ibtidaiyah, 2(1), hlm. 4 . https://media.neliti.com/media/p ublications/222455-kedudukanilmu-pengetahuan-sosial-ipspa.pdf
Richey, R. C., \& Klein, J. D. (2007). Design and Development Research Methods, Strategies, and Issues. Routledge. https://doi.org/https://doi.org/10 .4324/9780203826034

Richey, R. C., \& Klein, J. D. (2014). Handbook of research on educational communications and technology: Fourth edition. Handbook of Research on Educational Communications and Technology: Fourth Edition, 1-1005.

https://doi.org/10.1007/978-14614-3185-5

Rustini, T. (2016). Model Interaktif Dalam Pembelajaran IPS. EduHumaniora | Jurnal Pendidikan Dasar Kampus Cibiru, 4(1). https://doi.org/10.17509/eh.v4i1 .2818

Sapriya. (2009). Pendidikan IPS. PT Remaja Rosdakarya.

Siska, Y. (2016). Konsep Dasar IPS (1st ed.). Penerbit Garudhawaca.

Sumiharso, R., \& Hasanah, H. (2018). Media Pembelajaran: Buku Bacaan Wajib Dosen, Guru dan Calon Pendidik. Penerbit Pustaka Abadi.

Supriyono. (2018). Pentingnya Media Pembelajaran Untuk Meningkatkan Minat Belajar Siswa SD. Edustream: Jurnal Pendidikan Dasar, II(1), 43-48. https://journal.unesa.ac.id/index. php/jpd/article/view/6262/3180

Susantini, E., Puspitawati, R. P., \& Suaidah, H. L. (2021). E-book of metacognitive learning strategies: design and implementation to activate student's self-regulation. 